\title{
Entre os passos do samba e o compasso da ditadura:
}

\author{
Fissuras e censura em tempos de "Estado Novo"1
}

\section{ADALBERTO PARANHOS 2}

\begin{abstract}
Resumo. Uma mesma canção, calcada no binômio letra e música, admite distintas leituras associadas a diversas constelações de sentido. Ela não é um objeto inerte, congelado no tempo e no espaço, cristalizado a ponto de mostrar-se impermeável a flutuações e a migrações de significado. Conforme as performances vocais, instrumentais e visuais que informam $e$ conformam as canções, elas, em determinadas circunstâncias, podem vir a significar algo sequer imaginado pelos seus autores, configurando uma dança dos sentidos. Isso se aplica igualmente à análise de realidades históricas específicas. Um mesmo objeto - no caso, as relações entretecidas entre o "Estado Novo" e a área da música popular - é passível de ser apreendido sob diferentes prismas analíticos, na dependência, em grande medida, dos aportes teóricos e dos métodos de investigação a que nos agarramos como âncoras para levar adiante nossas pesquisas. Sob essa perspectiva, hábitos monológicos não são, nem de longe, bússolas confiáveis quando procuramos dar conta do caráter dialético das relações políticas e dos artefatos musicais. É disso que trata este texto ao pisar e repisar, uma vez mais, o chão muito batido da ditadura estadonovista para surpreender a existência de práticas discursivas que colocam em xeque certos pressupostos tradicionais da historiografia largamente disseminada sobre o período. Afinal, para além de colecionarem silêncios e/ou de se recolherem ao papel de câmaras de eco da "palavra estatal", outras vozes, destoantes ou dissonantes, se fizeram ouvir também na época, apesar da censura que pesava sobre elas, asfixiando-as.
\end{abstract}

Palavras-chave: Dança dos sentidos. Música popular. "Estado Novo". Censura. Vozes destoantes.

\footnotetext{
${ }^{1}$ Este artigo se baseia na intervenção do autor numa das sessões da websérie "Arte e cultura em tempos de censura no Brasil", ocorrida em 15 de abril de 2021, live integrada aos eventos ligados ao projeto Cultura na UFG, coordenado pela Prof. ${ }^{a}$ Dra. Flavia Maria Cruvinel, pró-reitora adjunta de Extensão e Cultura e diretora da Cultura da Universidade Federal de Goiás. Busquei, então, atender à solicitação que me foi formulada de revisitar as teses centrais do meu livro Os desafinados: sambas e bambas no "Estado Novo" (PARANHOS, 2015). À minha colega e amiga Martha Ulhôa externo os agradecimentos pelo incentivo à publicação deste texto. A pesquisa desenvolvida se beneficiou de recursos provenientes da FAPEMIG (Edital Universal) e do CNPq (bolsa PQ).

2 Doutor em História pela PUC-SP, com pós-doutorado em Música pela UNICAMP. Professor do Programa de Pós-Graduação em História da Universidade Federal de Uberlândia. Pesquisador do CNPq. E-mail: akparanhos@uol.com.br
} 


\title{
Between samba steps and dictatorial beat: fissures and censorship in "Estado Novo" times
}

\begin{abstract}
The same song, based on the lyrics and music binomial, allows for different readings associated with various constellations of meaning. It is not an inert object, frozen in time and space, crystallized to the point of being impervious to meaning fluctuations and migrations. According to vocal, instrumental and visual performances that inform and form songs, these can, under certain circumstances, come to mean something their writers had not even imagined, thus configuring a dance of meanings. This also applies to the analysis of specific historical realities. The same object -in this case, the intertwining of "Estado Novo" and popular musiccan be understood under different analytical lights, depending, to a great extent, on the theoretical contributions and research methods that we hold on to as anchors in carrying out our research. From this perspective, monological habits are by no means reliable compasses when we seek to account for the dialectical character of political relations and musical artifacts. That is what this text is about, as it walks once more the much-trodden ground of the "Estado Novo" dictatorship to surprise the existence of discursive practices that call into question certain traditional assumptions of the widely disseminated historiography about that period. After all, in addition to collecting silences and/or confining themselves to the role of echo chambers of the "State-uttered word," other voices, discordant or dissonant, also made themselves heard at that time despite the censorship that weighed on them, stifling them.
\end{abstract}

Keywords: Dance of meanings; popular music; "Estado Novo"; censorship; dissonant voices.

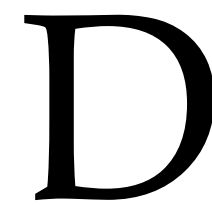

urante o "Estado Novo", piscaram os sinais de alerta para os malandros e todos que cultuavam a malandragem. Com a criação do Departamento de Imprensa e Propaganda (DIP), ${ }^{3}$ em 27 de dezembro de 1939, a censura às vozes destoantes da ideologia estado-novista foi desencadeada com redobrado vigor. A mão de ferro da ditadura intensificou a repressão à vadiagem, e ganhou corpo a perseguição a quem exaltasse o não trabalho.

Preocupados em polir a imagem do Brasil como uma nação constituída por trabalhadores de todas as classes, os governantes não se dispunham a assistir, sem esboçar reação, à glorificação da orgia e à celebração da malandragem. Ideologicamente, os doutrinadores de plantão assemelhavam a greve à ociosidade. E

\footnotetext{
${ }^{3}$ Um extenso feixe de poderes era abarcado pelo DIP. No cumprimento da função de promover o engrandecimento do regime e de exercer o papel de censor, seu raio de alcance envolvia cinco divisões: Divulgação, Imprensa, Radiodifusão, Cinema e Teatro e Turismo (GOULART, 1990, p. 62-87; PARANHOS, 2007, p. 102-108).
} 
ócio, afirmava um deles, Azevedo Amaral (1941, p. 50 e 86), era irmão siamês da "boêmia improdutiva", uma "perversão" do "instinto da ordem".

$\mathrm{O}$ ar político sob o qual se vivia era turvo e tenso. Um escritor contemporâneo, Marques Rebelo (2002, p. 117 e 51), escreveria em seu diário-romance que "o clima que se respira [...] é o do medo, da delação, da espionagem", até porque “as paredes são de papel”. Para além das intervenções nos sindicatos de trabalhadores, das perseguições aos opositores, do cortejo de prisões arbitrárias, torturas e mortes, nem sequer Tarzan, o invencível escapava da sanha ditatorial do "Estado Novo". 4

Tal qual a unha adere à carne, o novo samba urbano carioca, que teve no bairro do Estácio de Sá o seu centro de propulsão, soldara o sambista ao malandro. Desatar esse nó era tarefa concebida como urgente e inadiável. Vargas, as instituições estatais e as "pessoas de bem" deveriam mover um combate sem tréguas à malandragem tradicional.

Dos propósitos à ação, tudo se passou sem perda de tempo: o Estado apontou suas armas para os redutos da malandragem carioca. Seu símbolo-mor, a Lapa, virou alvo preferencial da polícia e dos rearranjos urbanos que redundaram na reabertura da temporada de desapropriações em massa para dar passagem à "modernidade" e à "civilização". A ideologia do regime, num certo sentido, se materializava em medidas drásticas. ${ }^{5} \mathrm{E}$ os personagens da Lapa e de todas as lapas do Rio estavam predestinados a receber um tratamento de choque.

Nesse contexto, os compositores populares, em especial os sambistas, começaram a ser estrita e estreitamente vigiados. Paralelamente, procurava-se atrair os artistas para a área de influência governamental: usando a moeda de troca dos favores oficiais, tentava-se capturá-los na rede do culto ao trabalho. Escorada na atuação do DIP, a ditadura objetivava assegurar a instauração de um determinado tipo

\footnotetext{
${ }^{4}$ Enquanto se realizavam autos de fé ou espetáculos públicos de "purificação" das ideias, com a incineração de livros em diversos pontos do país, no Rio de Janeiro uma batida policial em livrarias resultaria na apreensão, entre outros, de Capitães de areia, de Jorge Amado, e de Tarzan, o invencível, este incriminado pelo fato de esse herói de histórias em quadrinhos utilizar a expressão "camarada", procedimento considerado típico de comunistas (CARNEIRO, 1999, p. 330-331).

${ }^{5}$ A materialidade da ideologia é elemento intrínseco à concepção de Antonio Gramsci (2001, p. 78), para quem o "material ideológico" abrange "até a arquitetura, a disposição e o nome das ruas".
} 
de sociedade disciplinar, simultaneamente à fabricação de um perfil identitário do trabalhador brasileiro dócil à dominação capitalista.

Em que medida isso reverteu em resultados positivos, a ponto de calar a tradição de exaltação à malandragem no campo do samba, é o que tenciono examinar aqui. Para tanto, abrirei espaço principalmente às vozes dissonantes do grande coral que, a depender dos desígnios do "Estado Novo", entoaria em uníssono um "samba de uma nota só", com loas aos "novos tempos" e à disciplina no mundo do trabalho este, em particular, é um tema bastante caro à burguesia.

\section{A censura e as fissuras das vozes destoantes}

E aí o DIP foi acionado. A tesoura da censura, com sua lâmina de corte afiada, operava com desenvoltura. Inegavelmente, sua ação granjeava simpatia por responder também a apelos de diferentes setores da sociedade brasileira. Nessas circunstâncias, registravam-se novos apertos no parafuso. Uma coisa, porém, é constatar as pressões e os cerceamentos que tolhiam a liberdade dos sambistas; outra, inteiramente distinta, é endossar a tese corrente sobre o silenciamento das vozes destoantes do catecismo oficial, quer por força da repressão, quer por força da propagação das ideias incensadas pelo "Estado Novo".

Imprensados entre a ideologia do trabalhismo, as leis promulgadas pelo governo Vargas, supostamente em benefício dos trabalhadores, e sofrendo os efeitos da mão pesada das forças repressivas, teriam, finalmente, os compositores e intérpretes da canção popular, senão aderido à ordem estabelecida, pelo menos calado o que sua voz trazia de inconveniente aos valores vigentes?

Para um destacado pesquisador da história da música popular no Brasil, o jornalista Sérgio Cabral (1975, p. 40), não há maiores dúvidas quanto aos superpoderes ostentados pelo Estado, notadamente pelo DIP, em relação ao controle da produção musical e ao estímulo ao enaltecimento do trabalho. Sem meias palavras, ele garante que, a partir de 10 de novembro de 1937 (data de sua instalação), o regime "tinha 
absoluto controle da música popular brasileira e de qualquer tipo de manifestação a ela relacionada" ${ }^{6}$

Texto que se tornou célebre nos meios acadêmicos, onde continua ecoando até hoje, "Getúlio Vargas e a música popular brasileira" se converteu em referência obrigatória nos estudos voltados para essa questão, quando não para a discussão mais geral sobre o "Estado Novo" e sua ação político-cultural. Tais trabalhos, ao cristalizarem uma visão unívoca, originaram ou simplesmente reforçaram alguns malentendidos que cercam o assunto. E, ao mesmo tempo que contribuíram para superestimar o poder estatal, acabaram por reproduzir, consciente ou inconscientemente, ainda que por vias oblíquas, o próprio discurso oficial a respeito do caráter uno do Estado, que teria logrado alcançar um grau de plena identificação entre ele e a nação, ao agir como o tradutor de seus anseios mais profundos. ${ }^{7}$

Deslocando o debate para o nível teórico, a meu ver, muitos autores, ao fim e ao cabo, acatam, sob vários aspectos, a "teoria do rebaixamento" a que se refere Peter Burke (1998, p. 84-90). Passam ao largo do processo de interação entre os sujeitos, quaisquer que sejam eles e quaisquer que sejam as suas reservas de poder. Os conteúdos manipulados pelo agente transmissor, no caso o Estado/DIP, teriam sido interiorizados sem mais pelos receptores. Em síntese, o receptor é praticamente reduzido a locutor da fala alheia ao ser rebaixado à condição de "locutor-papagaio". Assim se perde de vista uma lição lapidar de Raymond Williams (1969, p. 322), que, nos anos 1950, já nos ensinava que "a comunicação não é somente transmissão; é, também, recepção e resposta", razão pela qual é imprescindível admitir que a fala do emissor está sempre sujeita a reapropriações e redefinições ou rejeições.

Ora, hegemonia não se confunde com dominação ou imposição absoluta, muito menos com uniformização (PARANHOS, 2015, p. 12-45). Isso se aplica a todas as áreas, inclusive à cultural. Como sustenta Thompson (1998, p. 17), "na verdade o próprio termo 'cultura', com sua invocação confortável de um consenso, pode distrair

\footnotetext{
${ }^{6}$ De acordo com Cabral (1975, p. 41), "as brechas contra a censura do DIP só iriam surgir com a entrada do Brasil na guerra, quando, a pretexto de espinafrar os nazistas, os compositores arranjavam um jeito de exaltar a democracia. Mas outros compositores preferiam exaltar o próprio Getúlio".

${ }^{7}$ Minhas reflexões críticas acerca da produção acadêmica sobre as relações entre Estado Novo e a música popular se acham condensadas em Paranhos (2015, p. 111-115).
} 
nossa atenção das contradições sociais e culturais, das fraturas e oposições existentes dentro do conjunto". E as fraturas, como se fossem fissuras sobre uma superfície plana, teimavam em se manifestar sob o "Estado Novo", por mais que ele buscasse obturálas.

O cerco do silêncio que se montou em torno das práticas e discursos que destoavam das normas instituídas levou muita gente, por muito tempo, a acreditar no triunfo de um pretenso "coro da unanimidade nacional" sob aquele regime de ordem unida. No fundo, a sociedade brasileira se limitaria a ser mera câmara de eco da fala estatal, que, para impor-se, contaria com um sem-número de meios de coerção e de construção de consenso.

Ao romper com essa ótica e puxar o fio da discussão para o terreno da música popular brasileira, eu procuro levantar uma parte do véu que encobre manifestações que desafinaram o "coro dos contentes" durante o "Estado Novo". Se calibrarmos o foco da investigação concreta sobre a produção fonográfica dessa época, será possível recolher novas evidências para informar outras análises. De resto, como salienta Robert Darnton (2001, p. XIV), “sempre é possível fazer perguntas novas ao material antigo". A despeito da férrea censura do DIP, adquirem importância as "lutas de representações"8 que giram ao redor do trabalho e do trabalhador. Na prática, se, de um lado, houve um elevado número de composições e compositores populares afinados pelo diapasão estado-novista e com a valorização do trabalho, de outro despontaram, como uma espécie de discurso alternativo, canções (sambas, em sua maioria) que traçaram linhas de fuga diante da "palavra estatal".

\section{Por uma história "a contrapelo"}

Em uma de suas famosas teses sobre a história, a sétima, Walter Benjamin (1985, p. 225) se afasta do conjunto das narrativas consagradoras dos vencedores e

\footnotetext{
${ }^{8}$ Bourdieu (2002, p. 113 e 118) adverte-nos para a relevância das lutas de representações. Ele insiste na necessidade "de se incluir no real a representação do real ou, mais exatamente, a luta das representações", pois a "'realidade' [...] é o lugar para uma luta permanente para definir a 'realidade'", o que supõe uma "luta para fazer existir ou 'inexistir' o que existe".
} 
enfatiza que o materialista histórico “considera sua tarefa escovar a história a contrapelo". ${ }^{9}$ Ao enveredar pelo "Estado Novo", é justamente o que me proponho, apurando o ouvido para captar outros sons que não apenas os alardeados pelo discurso oficial. Sem desconhecer a adesão espontânea, forçada ou interessada de muitos compositores populares à cantilena do regime, o que se nota em dezenas de discos é que, apesar dos pesares, o coro dos diferentes jamais deixou de se expressar, de modo mais ou menos sutil, conforme as circunstâncias.

Uma escuta fina dos fonogramas dos tempos estado-novistas com certeza nos reservará umas tantas surpresas, desde que se parta de um princípio metodológico: trabalhar com música requer que se ouçam os registros das canções. E mais, como recomendam Michel de Certeau e Luce Giard (2000, p. 338), implica nos libertarmos da "crença errônea na transparência significante dos enunciados, fora do processo de enunciação". Que nos sirva de advertência a gravação de "O amor regenera o malandro" (de Sebastião Figueiredo).

Neste samba, como em outros desse período, bate-se numa tecla persistente:

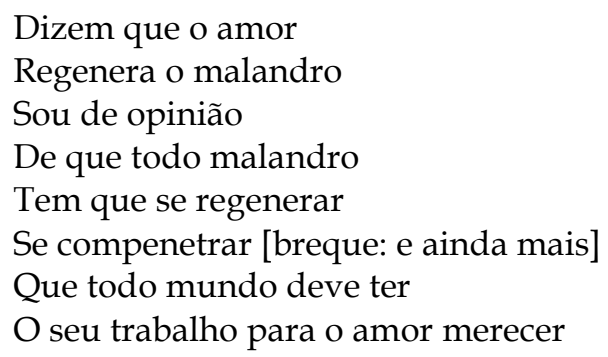

A primeira impressão, que sugere completa conformidade com o ideário trabalhista, se desfaz, entretanto, ao acompanharmos a performance dos intérpretes, Joel e Gaúcho, particularmente no final da segunda estrofe: "regenerado / ele pensa no amor / mas pra merecer carinho / tem que ser trabalhador (breque: que horror!)". O uso do breque a duas vozes - breque que, geralmente, é anunciador de distanciamento crítico - põe por terra todo o blá-blá-blá estado-novista que parecia haver contagiado a gravação.

9 Para uma explicação sintética sobre a potência criativa das teses de Benjamin, ver Löwy (2010/2011). 
Aqui, abro um parêntese para um aparte de natureza metodológica. Convém ficarmos alertas para o fato de que uma composição não existe tão somente no plano abstrato. Importa é o seu fazer-se, a formatação que recebe ao ser interpretada/reinterpretada. Nessa perspectiva, entendo que interpretar é também compor, pois quem interpreta decompõe e recompõe uma composição, podendo investi-la de sentidos não imaginados ou mesmo deliberadamente não pretendidos pelo seu autor. Disso decorre que não é suficiente examinar abstratamente uma canção, reduzida à peça fria da letra ou da partitura. Sua realização sonora, do arranjo à interpretação, tudo é portador de sentidos (PARANHOS, 2004). Não é à toa que Paul Zumthor (2001, p. 134 e 228) chama a atenção para “a riqueza expressiva da voz e aos valores que seu volume, suas inflexões, seus percursos atribuem à linguagem que ela formaliza", e arremata: "o intérprete [...] significa". ${ }^{10}$

É o que se verifica em "O amor regenera o malandro". Quem tomá-la ao pé da letra, ou melhor, quem se der unicamente ao trabalho de pesquisar as revistas de modinhas, nas quais se publicavam as letras das canções populares, se fixará no acessório e não apreenderá o principal. Restringir a análise aos seus versos nos conduz a lidar com a canção - por definição, uma obra musical revestida de letra - como não mais do que um documento escrito, amesquinhando seu raio de significações, o que pode nos fazer desconsiderar suas apropriações e reapropriações. Não basta inclusive o acesso à partitura. Nesse caso específico, ela não vai além da reprodução da letra da composição, sem os breques que lhe foram posteriormente incorporados. ${ }^{11}$ Obviamente, o último verso (com o respectivo breque, um caco introduzido no estúdio de gravação) não constava por inteiro da letra submetida ao crivo dos censores (Fig. 1).

\footnotetext{
${ }^{10}$ Bourdieu (2001, p. 253), por sua vez, complementa: "às vezes, o essencial do que diz um texto ou um discurso está naquilo que ele não diz. Está na forma em que o diz, está na entonação".

${ }^{11}$ Que isso valha como mais uma advertência, a exemplo da formulada por Richard Middleton (1990, p. 105), ao criticar o império da partitura, do qual deriva o "centrismo notacional". Por outro lado, remete-nos, entre outros, a Christopher Small (1999, n.p.), para o qual "no hay música aparte de la actuación, sea em vivo o grabada". Para a audição de "O amor regenera o malandro", acessar https://bit.ly/joel_e_gaucho.
} 
Fig. 1: Partitura de "O amor regenera o malandro" - A Melodia, Rio de Janeiro [1934?]

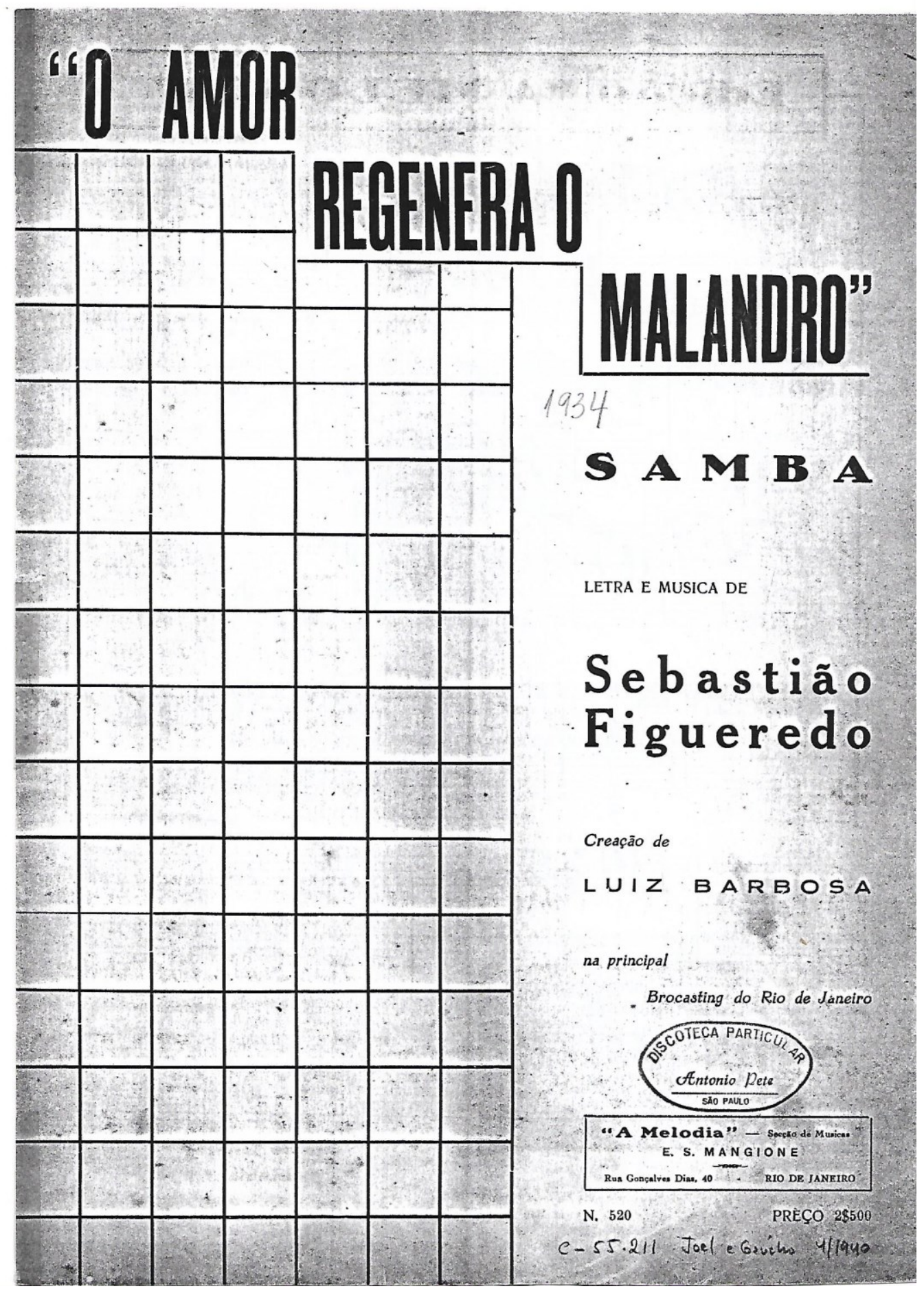




\section{"O AMÔR REGENERA O MALANDRO"} Samba
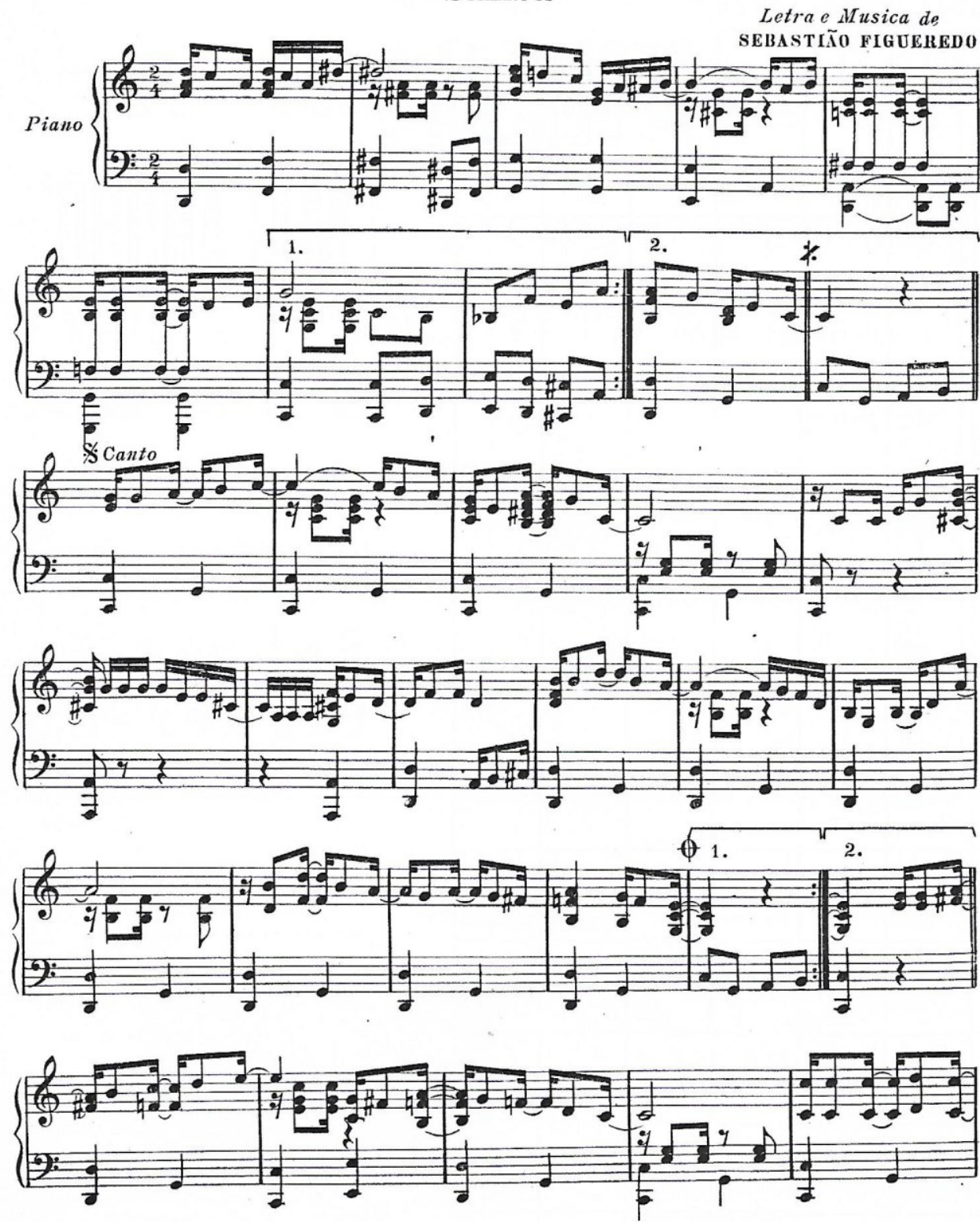

Direitos autoraes reservados par a todos os paizes

Edigão "A Melodia" E. S. Manyione S. Paulo-Rio E.S. M. 520 

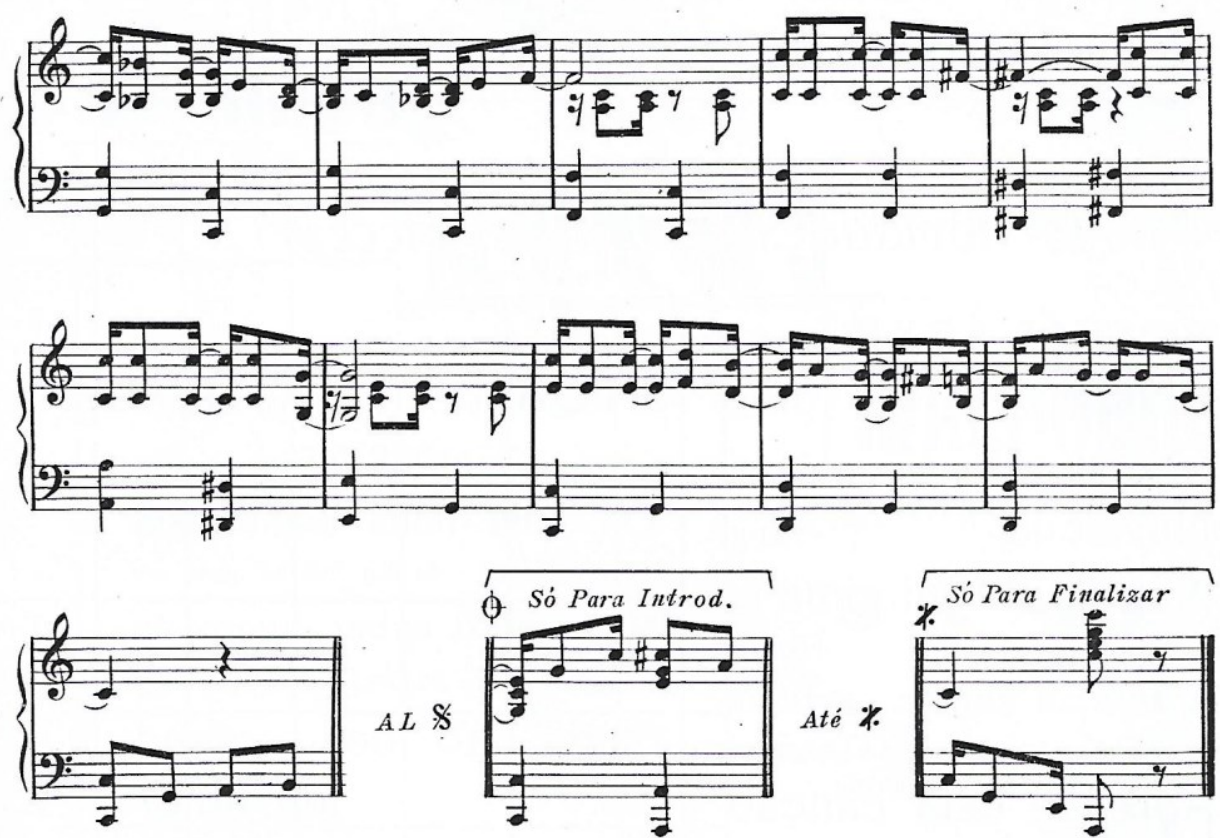

$A L \oiint$
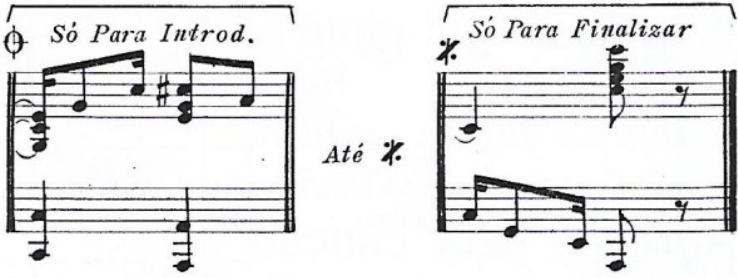

Estribilho

DIZEM QUE O AMOR REGENERA O MALANDRO.

SOU DE OPINIÃO

QUE TODO MALANDRO TEM QUE SE REGENERAR,

AINDA MAIS

SE COMPENETRAR

QUE TODO O HOMEM DEVE TER

O SEU TRABALHO PARA O AMOR MERECER.

$I$

Malandro regenerado É que tem o seu valor. E sempre cotado.

Quer no samba ou no amor.

Com boa conversa

Obtem tudo o que quer.

Dinheiro näo lhe falta

Nem carinho de mulher.

(Dizem que o amor etc...)
II.

O malandro quando canta.

Lembra logo sua magua.

Tendo o coraçäo ferido

$E$ os olhos rasos d'agua.

Regenerado elle pensa no amor

Mas p'ra merecer carinho

Tem que ser trabalhador.

(Dizem que o amor etc...)

Fonte: Acervo particular de Abel Cardoso Junior

Tal registro permite entrever o nexo existente entre a performance da dupla e as práticas musicais de Joel de Almeida, que, nas águas do cantor e "percussionista" Luiz Barbosa - um dos pais do samba de breque - transformou o chapéu de palha, fora 
o pandeiro, no seu instrumento de percussão preferido. Numa sua interpretação cheia de bossa, de cabo a rabo, Joel e Gaúcho se comportam malandramente. Eles quebram a aparente harmonia refletida na letra e subvertem seu conteúdo original. Comportamento, aliás, tipicamente malandro: há a aparente aceitação das regras instituídas como simples estratégia de sobrevivência. Segundo os códigos da malandragem, a arte da dissimulação é ponto de honra, como ressaltam Gilberto Vasconcellos e Matinas Suzuki Jr. (1984, p. 520); daí não ser sinal de inteligência oferecer-se como caça ao caçador. De mais a mais, uma composição não se prende irremediavelmente a um sentido fixo, congelado no tempo e no espaço, antes podendo migrar de sentido em certas situações. E aqui nos colocamos diante de uma situação característica de um “discurso bivocal”. Por meio dele, esclarece Bakhtin (1981, p. 168), "a segunda voz, uma vez instalada no discurso do outro, entra em hostilidade com seu agente primitivo e o obriga a servir a fins diametralmente opostos. O discurso se converte em palco de luta entre duas vozes".

O verbo malandrar era conjugado em atos por muitos outros personagens da música popular brasileira. Alguns deles habitavam o mundo do compositor Assis Valente, mulato de origem humilde que dividia seu tempo entre a arte de fazer prótese dentária e a arte de compor. "Recenseamento" ilustra, à perfeição, os dribles aplicados na censura.

Cronista musical do cotidiano, Assis Valente se aproveita de um assunto que figurava na ordem do dia, o censo de 1940. Narra a subida ao morro do bisbilhoteiro agente recenseador que quis tirar a limpo toda a vida de um casal não casado e, entre outras coisas, "perguntou se meu moreno era decente / e se era do batente / ou era da folia". Frente a essa interpelação, a mulher (na pele de Carmen Miranda), que se declara "obediente a tudo que é da lei", foi logo se explicando:

O meu moreno é brasileiro

É fuzileiro

E é quem sai com a bandeira

Do seu batalhão...

A nossa casa não tem nada de grandeza

Mas vivemos na pobreza

Sem dever tostão

Tem um pandeiro, tem cuíca e um tamborim

Um reco-reco, um cavaquinho 
E um violão

O arremate é digno do mestre Assis Valente:

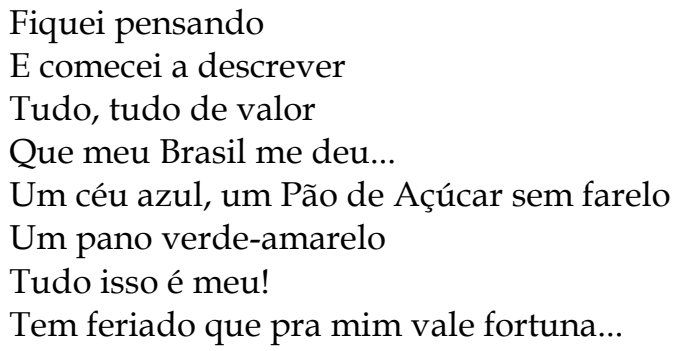

Eis uma obra que, parecendo reproduzir o discurso dominante do "Brasil grande e trabalhador" dos apologistas do "Estado Novo", desmonta com perspicácia os argumentos oficiais, salpicando de ironia a fala da mulher que responde ao funcionário que a entrevista. Seu "moreno", ao que tudo indica, nem de longe deveria ser catalogado no exército regular de "trabalhadores do Brasil", ele que seria talvez porta-bandeira (ou melhor, mestre-sala) de escola de samba. No barraco em que moravam, faltava tudo - imagem que contrasta com a do "Brasil novo" vomitada pela propaganda governamental. Tudo, em termos: não faltavam os apetrechos reclamados pelo samba. Afinal de contas, o que o "Estado Novo" lhes dera? O azul do céu, um cartão-postal (o Pão de Açúcar, ainda por cima sem farelo), uma bandeira (apequenada na menção a um reles "pano verde-amarelo"). De quebra, a louvação aos feriados entra em franca contradição com a idealização do trabalho, pedra de toque da ideologia do trabalhismo. ${ }^{12}$

No entanto, a mulher, à primeira vista, era toda felicidade. Nada de excepcional nisso: Noel Rosa e Ismael Silva, que entendiam do riscado, já não haviam assegurado, em "Escola de malandro", que "fingindo é que se leva vantagem / isso,

\footnotetext{
${ }^{12}$ As tentativas de enquadramento do samba nos dispositivos disciplinares do Estado Novo fugiram, em vários momentos, aos propósitos das autoridades. Um exemplo a mais é "Já que está deixa ficar", de Assis Valente, com os Anjos do Inferno. O eu lírico dessa canção conhece, de cor e salteado, os argumentos daqueles que investem contra os pecados do samba, recheado de gírias e de "propaganda do gostoso parati [cachaça]": "'abandona este sereno / pra você é um veneno / deixa desse tereré' / já ouvi alguém dizer / 'vai andando, seu vagolino [vagabundo] / pra criar calo no pé' / pois é". Nem assim ele se dobra ante a força de persuasão da pregação em prol do trabalho. Como quem faz ouvidos moucos a lenga-lenga, subentende-se que tal personagem prefere viver à base de expedientes e se dedicar ao samba em vez de se amarrar ao trabalho regular e metódico. Na sua visão, como ele proclama em alto e bom som no início desse samba: "está bom até demais / já que está deixa ficar"...
} 
sim, é que é malandragem"? Com uma esperteza a toda prova, Assis Valente entrecruza discurso e contradiscurso, extraindo dessa canção um resultado que se choca com o ideário do governo Vargas. Detalhe não desprovido de maior significação: "Recenseamento" é um samba-choro cantado despojadamente por Carmen Miranda, e o acompanhamento cria uma atmosfera musical típica das gafieiras... Aliás, nesse quesito, muitas gravações de sambas desse período, numa espécie de discurso nu de palavras, metiam-se em rota de colisão com um estilo retumbante. Ao contrário dos altissonantes e grandiloquentes adornos orquestrais que vestiam os sambas-exaltação - moldura grandiosa que se adequava à "grandeza" do Brasil e do regime -, gravações como a de "Recenseamento" eram confiadas a conjuntos chamados regionais, integrados por um número reduzido de músicos. ${ }^{13}$ Portanto, até nos aspectos estritamente musicais cavava-se uma distância considerável entre eles, o que, por certo, não excluía a possibilidade de canções feitas segundo a régua e o compasso do “Estado Novo" receberem um acabamento instrumental menos pretencioso.

Viremos a página. Quando ajustamos as lentes para enxergar melhor, por intermédio das canções, as representações da realidade social em movimento, deparamo-nos também com mulheres quebrando elos das cadeias dos padrões comportamentais serializados. Por sinal, é interessante constatar que a música popular foi e é um campo propício à expressão - dissimulada ou não, pouco importa - da fragilidade do "sexo forte". As lamentações, as queixas, as "dores de corno" encontraram nela um solo fértil. Retomando, en passand, Friedrich Engels (1960, p. 69 e 66), historicamente os homens se acreditaram os vencedores na "guerra dos sexos", mas as mulheres coroaram os vencedores... "Oh! Seu Oscar", gravada no segundo semestre de 1939, exemplifica bem o que digo. Com um adendo precioso: mais do que um estrondoso sucesso do carnaval de 1940, essa composição sagrou-se campeã do

\footnotetext{
13 Entre inúmeros exemplos disponíveis, confrontem-se o samba-exaltação "Brasil!", de Benedito Lacerda e Aldo Cabral, com Francisco Alves e Dalva de Oliveira, e o samba "Vida apertada", de Ciro de Sousa, com Ciro Monteiro. Em "Brasil!" compõe-se um quadro saturado de grandezas: o tom sinfônico da orquestra, baseado na protofonia de "O guarani", de Carlos Gomes, domina a abertura e o fecho da gravação, que catapulta o Brasil a "majestade do universo". Em "Vida apertarda", que desfia o rosário de lamúrias de um trabalhador, o arranjo é todo balançado, entrecortado por breques, desde o começo com um breque ao piano. É igualmente perceptível o tom mais coloquial do cantor Ciro Monteiro, que se diferencia das interpretações mais empostadas do "rei da voz" Francisco Alves e de Dalva de Oliveira, inspiradas no bel canto.
} 
concurso de sambas carnavalescos patrocinado pelo DIP, no Rio de Janeiro. Para tanto, jogou a seu favor, evidentemente, o fato de um dos papéis centrais da história por ela narrada ser protagonizado por um trabalhador.

Do que trata esse samba de Ataulfo Alves e Wilson Batista, na voz de Ciro Monteiro? "Seu Oscar", "cansado do trabalho", mal chega em casa, a vizinha lhe entrega um bilhete escrito pela sua mulher. E “o bilhete assim dizia: / 'não posso mais / eu quero é viver na orgia!'”. ${ }^{14}$ Consumada tal situação, ele se desmancha em lamentos, inconsolável, na segunda parte da canção:

Fiz tudo para ver seu bem-estar
Até no cais do porto eu fui parar
Martirizando o meu corpo noite e dia
Mas tudo em vão, ela é da orgia

Essa mulher e tantas outras que caíam na folia, com uma vida relativamente liberada das amarras convencionais, não eram, em hipótese alguma, compatíveis com a figura feminina idealizada pelo ministro do Trabalho Marcondes Filho (1943, p. 5155; 1942, n.p.), ao exaltar "a senhora do lar proletário", que, para ele, evocava imagens ligadas à dona de casa, maternidade, prole e berços, o que resultaria na "divina fraqueza das mulheres". Correndo em outra raia, as mulheres "do barulho", "do balacobaco", "da pá virada”, que frequentavam os sambas compostos nesse tempo, infelicitavam os seus parceiros. Trocavam, com facilidade, as prendas domésticas pela gandaia, como se ouve em "Madalena", de Bide e Marçal, com os Anjos do Inferno, e os irritavam profundamente, como se nota em "Acabou a sopa", de Geraldo Pereira e Augusto Garcez, com Ciro Monteiro.

Afora isso, subsiste outro aspecto relevante a ser pontuado, por sugerir uma relativa ressignificação da mensagem musicada quando do registro em disco de "Oh! Seu Oscar": a palavra orgia é repetida nove vezes; os versos finais da primeira parte ("Não posso mais / eu quero é viver na orgia") são reiterados nada menos que sete vezes e assumem, sem dúvida, a condição de versos-chave da composição, servindo igualmente como desfecho da gravação. Alguém duvidará que, no calor do carnaval

\footnotetext{
14 Orgia, naquela época, era, sobretudo, sinônimo de festa, samba, batucada, boemia e coisas que remontam, sem a conotação de bacanal, entre os antigos romanos, ao deus Baco.
} 
de 1940, esse trecho tenha sido o que mais empolgou os foliões, fazendo os pratos da balança penderem para o lado da mulher pândega, e não para o do trabalhador ordeiro? O sugestivo acorde dissonante que se escuta ao fim, ao violão, parece indicar que, definitivamente, alguma coisa estava fora da ordem tida e havida como "natural", alguma coisa estava fora do lugar. De maneira sintomática, o título original de “Oh! Seu Oscar", que despertou reações moralistas - motivo pelo qual foi vetado -, era "Ela é da orgia". O romancista Marques Rebelo (2002, p. 179) lembra, a respeito disso, que a vingança popular contra o moralismo se expressou na consagração desse samba durante os festejos carnavalescos.

Paralelamente, acrescente-se que "seu Oscar", um trabalhador braçal (estivador), no seu desconsolo, afirma, sem rodeios, que "até no cais do porto eu fui parar / martirizando o meu corpo noite e dia". Como em um número elevado de sambas, o trabalho, em total descompasso com a ideologia do trabalhismo, é encarado e vivido como martírio, um duro fardo a ser suportado. E, como se isso não bastasse, ele, trabalhador - no limite hipoteticamente, um "malandro regenerado" -, é, na prática, convertido em otário, passado para trás por sua companheira. Se, como frisa Sueann Caulfield (2000, p. 337), as "políticas intervencionistas do "Estado Novo" reforçavam a dependência das mulheres em relação aos homens", nem todas elas se adequavam aos moldes do figurino estatal.

A mulher do "seu Oscar", ou melhor, nessa altura dos acontecimentos, a exmulher do "seu Oscar", não estava só. Outras personagens como que se juntavam a ela. Advertidas de que seu comportamento era censurável para mulheres "direitas" e "do lar", elas dispensavam tal tipo de aconselhamento. É o que se depreende de "Não quero conselho", de Príncipe Pretinho e Constantino Silva, gravado por Carmen Costa e Henricão. Amparado por uma cozinha rítmica esfuziante, a batucada produzida pelo conjunto de Benedito Lacerda, com o ronco onipresente da cuíca - como um discurso sem palavras, a reafirmar, musicalmente, a letra da canção -, fornece o enquadramento sonoro para a confissão de apego à boemia: "eu nasci pra boemia de verdade / e nela eu pretendo me acabar".

Havia, entretanto, quem procurasse refúgio em casa, a despeito das noites embaladas pela orgia, como aquela figura que confessava "que eu sou mesmo da folia 
/ chego em casa ao romper do dia" e apelava ao seu "nego" para que abrisse a porta, "que o sereno quer me apanhar". É o que se ouve no samba "Abre a porta", de Raul Marques e César Brasil, com Dircinha Batista, em cujo registro a flauta - tocada espertamente, como se sugerisse que essa mulher, toda faceira, queria levar a vida na flauta - sobressai do início ao fim. Por sinal, a mesma trama se desenrola em "Sambei 24 horas", de Wilson Batista e Haroldo Lobo, interpretado por Aracy de Almeida sob um clima típico de carnaval. O companheiro da foliona se nega a abrir a porta do "chatô", e ela, necessitada de descanso depois de tanto sambar em Madureira, apela, com a cara mais lambida, para os seus bons sentimentos: “ai, ai, ai, amor / não deixe sua pretinha no sereno / que ela vai se resfriar".

Outras sambistas iam além, como a mulher do "seu Oscar". Sem mais essa nem aquela, batiam em retirada de suas casas ou "barracos", deixando seus maridos (com ou sem aspas) a ver navios. Ao elegerem os lugares do samba como seu território natural, entregavam-se à boemia. É o que se retrata em "Louca pela boemia", samba de dois bambas do Estácio de Sá, Bide e Marçal, com Gilberto Alves, gravado com um arranjo fiel aos mandamentos dessa matriz do novo samba urbano carioca, que despontou na segunda metade da década de 1920.15 Abandonado, o homem verbaliza sua queixa:

\footnotetext{
Louca pela boemia, me abandonou Meu castelo dourado se desmoronou Entreguei a ela o destino meu Louca pela boemia, tudo esqueceu
}

Como quem puxa linha de carretel, poderia seguir por esse caminho, recolhendo, aqui e ali, mais e mais exemplos, como "Você não tem palavra", de Newton Teixeira e Ataulfo Alves, com o primeiro, e "Faz um homem enlouquecer", de Wilson Batista e Ataulfo Alves, com Ciro Monteiro. Contudo, os scripts desses sambas, uma espécie de filme de suspense às avessas, são por demais previsíveis para tornar a reiterar seus desenlaces, que convergiam para a decantada infelicidade de uns

\footnotetext{
${ }^{15}$ Tal estilo de samba, mais marchado, implicava, entre outros elementos, uma aceleração rítmica e um afastamento da feição amaxixada que marcava até então esse gênero. $\mathrm{O}$ "paradigma do Estácio" é esmiuçado por Carlos Sandroni (2001, p. 32-37).
} 
e a alegria de outras, por mais efêmera que fosse. De toda forma, um denominador comum os irmanava: o ideal de uma família trabalhadora feliz acalentado pelo "Estado Novo" 16 ruía por terra a golpes de notas musicais. Mesmo que isso desagradasse a censura, ela, como é comum, se revelava incapaz de bloquear todos os poros pelos quais pulsava a vida cotidiana, sem contar que os censores obedeciam, com certeza, a uma escala de prioridades cujo alvo número um apontava para o combate incessante aos contestadores do regime.

\section{Para além dos "hábitos monológicos"}

Enfim, pretendi salientar, neste breve sobrevoo, o caráter dialético da dominação social em meio às relações entretecidas entre o Estado e a área da música popular num determinado contexto histórico. Quando o assunto se volta para o "Estado Novo" e envolve as imbricações do mundo do trabalho e das artes musicais, a tradição historiográfica se pauta, em geral, pelo que Mikhail Bakhtin (1981, p. 239) denominou "hábitos monológicos". Tudo se passa como se fosse possível apagar os sinais que nos levariam a captar vozes destoantes do grande coro da suposta unanimidade nacional orquestrada pela ditadura estado-novista. Desconsidera-se que, até sob um drástico regime ditatorial e uma censura draconiana, os domínios da vida político-social operam como "campos de luta" ou "campos de forças", como enfatizam Pierre Bourdieu (2001, cap. IV) e E. P. Thompson (1998, cap. 2; 2001, p. 276).

Assim, ao interrogarmos mais a fundo certas evidências, sempre poderemos perceber, "por detrás das categorias unificadoras, indivíduos; por detrás da linearidade de percursos muito simples, os mil atalhos das intrigas particulares" (PERROT, 1998, p. 61). E quem se embrenha por esses atalhos, pelas bordas, estará mais habilitado para se dar conta de que os códigos disciplinares que o "Estado Novo" se empenhou para impor, a ferro e fogo e por intermédio de táticas de construção do consentimento, não triunfaram na proporção esperada pelos governantes. Falas dissonantes repontaram por todos os lados, por todos os cantos, numa demonstração

\footnotetext{
${ }^{16}$ A família brasileira era, como destaca Sueann Caulfield (2000, p. 332-333), “a metáfora central da ordem social".
} 
de que, por mais ditatorial ou pretensamente totalitário que seja um regime político, ele nunca se consegue silenciar por inteiro as dissidências ou as diferenças. Ao escavarmos as múltiplas camadas de sentido da produção musical do período, é inevitável concluir que muita gente não ajustou seus passos ao compasso da ditadura estado-novista.

Resumo da ópera. Chico Buarque (1978), com a maestria habitual, em sua comédia musical Ópera do malandro, ambientada nessa época, nos oferece a senha, em “O malandro n. 2", para respondermos à pergunta que atravessou todo este texto: teria o "Estado Novo" sido inteiramente bem-sucedido em seu esforço para sepultar de vez a malandragem enaltecida pelos bambas do samba e inculcar os valores difundidos pela ideologia do trabalhismo? Para tanto, o compositor propõe uma analogia entre o malandro e o indigente:

O cadáver / Do indigente

É evidente / Que morreu

E no entanto / Ele se move

Como prova / O Galileu 


\section{Referências}

ABRE A PORTA. Intérprete: Linda Batista. Compositores: Raul Marques e César Brasil. [S. 1.]: Odeon, 1940. 78rpm.

ACABOU A SOPA. Intérprete: Ciro Monteiro. Compositores: Geraldo Pereira e Augusto Garcez. [S. 1.]: Victor, 1940. 78 rpm.

AMARAL, Azevedo. Getúlio Vargas, estadista. Rio de Janeiro: Irmãos Pongetti, 1941.

BAKHTIN, Mikhail. Problemas da poética de Dostoiévski. Rio de Janeiro: Forense Universitária, 1981.

BENJAMIN, Walter. Sobre o conceito da história. In: BENJAMIN, Walter. Magia e técnica, arte e política. São Paulo: Brasiliense, 1985. p. 222-232.

BOURDIEU, Pierre. A identidade e a representação: elementos para a reflexão crítica sobre a ideia de região. In: BOURDIEU, Pierre. O poder simbólico. 5. ed. Rio de Janeiro: Bertrand Brasil, 2002. p. 107-132.

BOURDIEU, Pierre. A leitura: uma prática cultural: debate entre Pierre Bourdieu e Roger Chartier. In: CHARTIER, Roger (org.). Práticas da leitura. 2. ed. São Paulo: Estação Liberdade, 2001. p. 229-253.

BOURDIEU, Pierre. Le mort saisit le vif. As relações entre a história reificada e a história incorporada. In: BOURDIEU, Pierre. O poder simbólico. 5. ed. Rio de Janeiro: Bertrand Brasil, 2002. p. 75-106.

BRASIL! Intérpretes: Francisco Alves e Dalva de Oliveira. Compositores: Benedito Lacerda e Aldo Cabral. [S. 1.]: Columbia, 1939. 78 rpm.

BUARQUE, Chico. Ópera do malandro: comédia musical. São Paulo: Livraria Cultura, 1978.

BURKE, Peter. Cultura popular na Idade Moderna: Europa, 1500-1800. 2. ed. São Paulo: Companhia das Letras, 1998.

CABRAL, Sérgio. Getúlio Vargas e a música popular brasileira. Ensaios de Opinião, Rio de Janeiro, v. 3, n. 2 + 1, p. 36-41, 1975.

CARNEIRO, Maria Luiza Tucci. O Estado Novo, o Dops e a ideologia da segurança nacional. In: PANDOLFI, Dulce (org.). Repensando o Estado Novo. Rio de Janeiro: Editora FGV, 1999. p. 327-340. 
CAULFIELD, Sueann. Em defesa da honra: moralidade, modernidade e nação no Rio de Janeiro (1918-1940). Campinas: Editora da Unicamp, 2000.

CERTEAU, Michel de; GIARD, Luce. Uma ciência prática do singular. In: CERTEAU, Michel de; GIARD, Luce; MAYOL, Pierre. A invenção do cotidiano: morar, cozinhar. 3. ed. Petrópolis: Vozes, 2000. p. 335-342. v. 2.

DARNTON, Robert. O grande massacre dos gatos: e outros episódios da história cultural francesa. 4. ed. Rio de Janeiro: Graal, 2001.

ENGELS, Friedrich. A origem da família, da propriedade privada e do Estado. Rio de Janeiro: Vitória, 1960.

ESCOLA DE MALANDRO. Intérpretes: Noel Rosa e Ismael Silva. Compositores: Noel Rosa, Ismael Silva e Orlando Luiz Machado. [S. 1.]: Odeon, 1932. 78 rpm.

FAZ UM HOMEM ENLOUQUECER. Intérprete: Ciro Monteiro. Compositores: Wilson Batista e Ataulfo Alves. [S. 1.]: Victor, 1942. 78 rpm.

GOULART, Silvana. Sob a verdade oficial: ideologia, propaganda e censura no Estado Novo. São Paulo: Marco Zero: CNPq, 1990.

GRAMSCI, Antonio. Cadernos do cárcere: os intelectuais. O princípio educativo. Jornalismo. 2. ed. Rio de Janeiro: Civilização Brasileira, 2001. v. 2

JÁ QUE ESTÁ DEIXA FICAR. Intérprete: Anjos do Inferno. Compositor: Assis Valente. [S. 1.]: Columbia, $1941.78 \mathrm{rpm}$.

LOUCA PELA BOEMIA. Intérprete: Gilberto Alves. Compositores: Bide e Marçal. [S. 1.]: Odeon, 1941.

LÖWY, Michael. "A contrapelo": a concepção dialética da cultura - as teses de Walter Benjamin (1940). Lutas Sociais, São Paulo, n. 25/26, p. 20-28, 2. sem. 2010/ 1. sem. 2011. Disponível em: https://revistas.pucsp.br/index.php/ls/article/view/18578. Acesso em: 15 mar. 2021.

MADALENA. Intérprete: Anjos do Inferno. Compositores: Bide e Marçal. [S. 1.]: Columbia, 1942.

MARCONDES FILHO. A senhora do lar proletário (palestra irradiada em 1942 na "Hora do Brasil"). In: MARCONDES FILHO. Trabalhadores do Brasil! Rio de Janeiro: Revista Judiciária, 1943. p. 55-55.

MARCONDES FILHO. Discurso na solenidade de fundação da Legião Brasileira de Assistência. Boletim do Ministério do Trabalho, Indústria e Comércio, Rio de Janeiro, n. 98, out. 1942. 
MIDDLETON. Richard. Studying popular music. Philadelphia: Open University Press, 1990.

NÃO QUERO CONSELHO. Intérpretes: Carmen Costa e Henricão. Compositores: Príncipe Pretinho e Constantino Silva. [S. 1.]: Columbia, 1940. 78 rpm.

O AMOR REGENERA O MALANDRO. Intérpretes: Joel e Gaúcho. Compositor: Sebastião Figueiredo. [S. 1.]: Columbia, 1940. 78 rpm.

O MALANDRO N. 2 (“Die Moritat von Mackie Messer”). Intérprete: João Nogueira. Compositores: Kurt Weill e Bertolt Brecht, adaptação de Chico Buarque. In: ÓPERA DO MALANDRO DE CHICO BUARQUE. [S. 1.]: Philips, 1979. 2 LPs, faixa 17.

OH! SEU OSCAR. Intérprete: Ciro Monteiro. Compositores: Ataulfo Alves e Wilson Batista. [S. 1.]: Victor, 1939. $78 \mathrm{rpm}$.

PARANHOS, Adalberto. A música popular e a dança dos sentidos: distintas faces do mesmo. ArtCultura, Uberlândia, n. 9, p. 22-31, jul./dez. 2004. Disponível em: http://www.seer.ufu.br/index.php/artcultura/article/view/1367. Acesso em: 25 mar. 2021.

PARANHOS, Adalberto. O roubo da fala: origens da ideologia do trabalhismo no Brasil. 2. ed. São Paulo: Boitempo, 2007.

PARANHOS, Adalberto. Os desafinados: sambas e bambas no "Estado Novo". São Paulo: Intermeios: CNPq: Fapemig, 2015.

PERROT, Michele. Maneiras de caçar. Projeto História, São Paulo, n. 17, p. 55-61, 1998.

REBELO, Marques. A mudança. 3. ed., Rio de Janeiro: Nova Fronteira, 2002. (2. tomo de O espelho partido).

RECENSEAMENTO. Intérprete: Carmen Miranda. Compositor: Assis Valente. [S. 1.]: Odeon, 1940. $78 \mathrm{rpm}$.

SAMBEI 24 HORAS. Intérprete: Aracy de Almeida. Compositores: Wilson Batista e Haroldo Lobo. [S. 1.]: Odeon, 1944. 78 rpm.

SANDRONI, Carlos. Feitiço decente: transformações do samba no Rio de Janeiro (19171933). Rio de Janeiro: Jorge Zahar: Editora UFRJ, 2001.

SMALL, Christopher. El musicar: un ritual en el espacio social. Trans: Revista Transcultural de Música, S. l., n. 4, 1999. Disponível em: https:/ / www.sibetrans.com/trans/articulo/252/el-musicar-un-ritual-en-el-espaciosocial. Acesso em: 30 mar. 2021. 
THOMPSON, E. P. As peculiaridades dos ingleses e outros artigos. Campinas: Editora da Unicamp, 2001.

THOMPSON, E. P. Introdução: costume e cultura. In: THOMPSON, E. P. Costumes em comum: estudos sobre a cultura popular tradicional. São Paulo: Companhia das Letras, 1998. p. 13-24.

THOMPSON, E. P. Patrícios e plebeus. Costumes em comum: estudos sobre a cultura popular tradicional. São Paulo: Companhia das Letras, 1998. p. 25-85.

VASCONCELLOS, Gilberto; SUZUKI JR., Matinas. A malandragem e a formação da música popular brasileira. In: FAUSTO, Boris (dir.). História geral da civilização brasileira - III - O Brasil republicano (Economia e cultura: 1930-1964). 3. ed. São Paulo: Difel, 1984. p. 501-523.

VIDA APERTADA. Intérprete: Ciro Monteiro. Compositor: Ciro de Souza. [S. 1.]: Victor, $1940.78 \mathrm{rpm}$.

VOCÊ NÃO TEM PALAVRA. Intérprete: Newton Teixeira. Compositores: Newton Teixeira e Ataulfo Alves. [S. 1.]: Odeon, 1940. 78 rpm.

WILLIAMS, Raymond. Cultura e sociedade: 1780-1950. São Paulo: Companhia Editora Nacional, 1969.

ZUMTHOR, Paul. A letra e a voz: a "literatura" medieval. São Paulo: Companhia das Letras, 2001. 